\title{
Ombilin Coal Mine Site: History and Potential as a Learning Source for the History of the Economy Based on Outdoor Learning
}

\author{
Rosmiati $^{1}$, Anny Wahyuni ${ }^{2}$, Amir Syarifuddin ${ }^{3}$ \\ ${ }^{1,2,3}$ Faculty of Teacher Training and Education, Universitas Jambi, Indonesia \\ Rosmiati@yahoo.com
}

\begin{abstract}
This study aims to determine the history of the Ombilin Sawahlunto coal mine, the use of this site as a historical learning resource based on outdor learning and the obstacles it faces in its utilization. The method used in this research is qualitative with a descriptive approach. The sources used were interviews, literature and newspapers. After collecting the sources and separating the primary and secondary sources, rewrite them. The research results found that government projects in the city of sawahlunto consist of three projects including first, exploitation of coal mines, second, construction of railways, third, construction of the port of Emmahaven (Teluk Bayur). Traces of Dutch heritage that still exist today are the railway museum, Goedang Ranseum, Mbah Soero Mine Hole, and the Coal Mining Museum. This legacy can be used as a source of historical learning based on outdor learning.
\end{abstract}

\section{Keywords}

jigsaw learning model; cooperative learning; outcomes

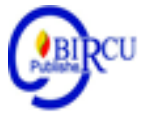

\section{Introduction}

This Economic History course contains a series of knowledge about the concepts of Economic theory, economic history, and the socio-economic development of Indonesia from prehistoric times, to the European colonial era, one of which is the Netherlands to the latest period of the 21st century in Indonesia, by emphasizing the discussion of thematic history (topical). This economic history course is not only a lecture in the classroom but requires field courses because the learning resources in this course are not only limited to books, modules and economic history dictates but there are historical sites.

Historical sites are learning resources that can use outdoor learning models. Outdoor learning model is able to hone student creativity in lectures, foster a spirit of independence, cooperation between students, train to control emotions and foster scientific attitudes suitable for use in historical sites. Historical sites are related to areas that have cultural heritage objects that can be used as learning resources. A site that can be used as a source of learning about economic history is the Ombilin Coal Mine which is located along the hillside line of the Sawahlunto Sijunjung district, West Sumatra Province. This mine is the only underground coal mine in Indonesia and is the oldest mine in Southeast Asia for coal.

Learning local history is the study of the life of a particular community or community in the dynamic development of human life. Meanwhile, Warsino in Rizqi (2020) believes learning local history can increase a sense of concern and interest in their regional areas, to explore more deeply about anything that is on the past trajectory in their area. Based on these two views, the researcher seeks to foster interest in student learning at the Vocational High School in Pringsewu Regency through local history material. 
Learning resources play an important role in the learning process in lectures to help facilitate student understanding of course material, especially economic history. Learning resources for this history study program consist of coal mining sites, temples, and ancient human fossils that can be used by students for learning activities so that the quality of learning for the better. This site deserves to be used as a learning resource for economic history because first, the coal mining industry in the colonial era had shown the development of pioneering technology that combined European mining engineering expertise with traditional practices that demonstrated the local environmental wisdom of West Sumatra. Second, the Triumvirate Concept which was initiated by the Dutch East Indies government during the colonialism era included the coal mining industry, the railway system and the port of Emmahaven (Teluk Bayur) which played an important role in the economic and social development of West Sumatra. Third, the cultural values in coal mining activities owned by the Sawahlunto community, which illustrate the dynamics of social and cultural interactions between the eastern and western world that have succeeded in transforming remote areas into dynamic and integrated urban areas.

\section{Review of Literatures}

\subsection{History of Ombilin Coal Mine}

The Ombilin Coal Mine was discovered by the Dutch colonial government starting in the 18th century marked by the discovery of a steam engine in Western Europe which brought changes in the industrial sector causing an increase in demand for coal. Initially, coal was only used for heating the room during winter in European countries, cooking food and household needs, now increasing its use for various large industries. At that time coal was used for trains, steamships, and various other types of industry. Coal has an important role in economic activity before the discovery of oil and other fuel sources.

Western countries such as France, England and the Netherlands compete with each other to explore and exploit coal mines in their colonies in Asia. The Dutch colonial government, earlier than the British and French, had started a coal search business in Asia, especially in the Dutch East Indies (State of Indonesia now). The Netherlands sent W.H. De Greve (geologist) to conduct research on various mineral content of mining materials in the Dutch East Indies. On May 26, 1867, he was assigned to investigate coal in the OmbilinSawahlunt area, this was the second investigation carried out by the Dutch colonial government because the first investigation failed. De Greve found a coal seam in the ulu Air bank of the Ombilin River. He found a coal "black gold" resource that was estimated at more than 200 million tonnes. The distribution is in the areas of Parambahan, Singaloet, Lembang Soegar, Sungau Durian, Rasau rice fields and Tanah Hitam.

De Grave in 1870 officially reported the results of his research to the Dutch East Indies government in Batavia. The contents of the report include Ombilin-Sawahlunto coal, calculation of the economic potential of coal, transportation (how to carry the coal), the chosen transportation route. When De Grave's research report reached a number of private investors, they submitted an application to the colonial administration for concessions, but the minister did not read and replied to the application because the minister was waiting for De Grave's latest research results, he returned to search in West Sumatra for a second time, however, De Grave had an accident along the Indragiri river route in 1872 and died. Then exploration was continued by R.D.M Verbek and supported De Grave's discovery and 
estimated that there were 100 tons of coal reserves that could be produced every year to meet coal needs in the Dutch East Indies.

J.L. Cluysenaer and D.D.Veth took part in exploration the following year but their focus was on building a railroad from the mining site (exploitation) to the port. J.A. Hoze was also deployed to design supplies for everything related to extracting coal. Since the discovery of coal in Sawahlunto, there has been a change in engineers and various experts were sent by the Dutch colonial government with the aim of preparing supporting infrastructure and infrastructure for coal mining.

The opening and exploitation of Ombilin coal in Sawahlunto had various impacts on the lives of Indonesian people. This project requires a lot of labor, costs, means of transportation, roads, railroads, ports, sea ships, mining equipment, office buildings, workers' residences and houses for mine officials and engineers must be provided. The economic development project was created by the Dutch colonial government as a triad. This triad includes the first, exploitation of coal mines, second, the construction of a railroad with the aim of bringing coal from Sawahlunto to the port of Emmahaven (Teluk Bayur), third, the construction of the port of Emmahaven (Teluk Bayur) in Padang with the aim that it can be distributed to European countries. This triad project must be integrated and must not fail because it will affect later. This project is financed by the State (Kingdom of the Netherlands) and is not submitted to the private sector with a note that it will not exceed the stipulation of the Dutch East Indies government, namely 5.7 million Golden and a profit which will be predicted to be $9 \%$ of this coal profit.

Coal mining is carried out by Indonesian people from various regions with their forced labor system in chains on their feet, hands and necks called chain people. These people in chains came from Dutch political prisoners (people who fought against the Dutch colonial government), robbers (people who robbed the houses of rich Dutch people) and criminals. Mining activities are divided into 3 shifs. The first shift starts from 6 a.m. to 2 p.m., the second shif starts from 2 p.m. to 10 p.m., and the third shift from 10 p.m. to 6 a.m. Once every two weeks, these teams are replaced with the composition of members who do not change (one a team consisting of 5 to 7 members) led by a foreman. For chain people who work the first shift must wake up early (04.00 WIB) with the aim of being able to pack early for bathing and prayer and having breakfast with handcuffed feet and hands, then chain again by the Dutch colonial government so that they do not easily escape. The division of the work of the chain people is seen from their physical appearance, those who are physically strong and fat are ordered to work in holes, breaking charcoal, carrying heavy logs into the holes to support the mine holes. The chain person who is physically weak is asked to be a nurse for his sick friend and select coal according to its size.

Land used in connection with this railway line is given compensation only once and the land will fall into the property of the Dutch government, if an agreement is not reached it will be resolved in court, the total compensation they provide is f.1.893.136.24 with a gradual grant over time development. To realize the railway line development, in 1889 A. Derx (head of Railways) made a visit to West Sumatra with the aim of preparing construction and bargaining for compensation for the land to be used. Land in West Sumatra is a land that cannot be traded but can be mortgaged.

The final agreement occurred by involving the mother of each of the people who lived there as well as the Domein declaration which aimed to explain the legal basis for the colonial government to grant civil rights to land according to colonial theory. Unexpectedly, the Dutch colonial government, the cost of land acquisition, cost quite a lot of money, there were differences in land prices on the islands of Java and Sumatra. 
A chain person was also hired to build a railway line, starting from Padang on 6 July 1889 for transporting coal from sawahlunto. The construction of the first train, namely from the island of Aie (Padang) to Padang Panjang, was completed on July 12, 1891, construction was continued from Padang Panjang to Bukittinggi until it was completed on November 1, 1891, after which it was built towards Solok (July 1, 1892). The railway line from Solok to Muara Kalaban coincided with the completion of the line construction from Padang to Teluk Bayur in October 1892. The Muara Kalaban route to sawahlunto was completed in early February 1894. The heaviest obstacle was encountered from Muaro Kalaban to Sawahlunto. $828 \mathrm{~m}$.

In 1894 the distribution of coal from sawahlunto to Teluk Bayur began by train. Along the railway line, five coal haulage stops were built, namely:

a. Sawahlunto Solok $(28.3 \mathrm{~km})$

b. Solok Batutaba $(33.2 \mathrm{~km})$

c. Batutaba Padang Panjang $(17,5 \mathrm{~km})$

d. Padang Panjang Planting Timber $(15.5 \mathrm{~km})$

e. Timber Planting at Teluk Bayur Harbor (Emmahaven) $(57 \mathrm{~km})$

The topography of West Sumatra, which has many hills, causes the railway line to have many inclines and turns, so it takes up to 10 hours to bring coal from the producing area to the port, Railroad construction project. Development carried out by the Dutch colonial government led to accelerated mobility, economic growth and the socio-cultural life of the people at that time. From an economic point of view, apart from facilitating the transportation of coal, plantation products are starting to be easily distributed and exported from the rural areas. The formation of new settlements along the railroad tracks, especially near stations, and an increasing number of markets at that time. In the sawahlunto area there is a mixture of cultures, there are Javanese, Chinese and other cultures as a result of people who are brought as forced laborers (chain people) coming from various ethnicities. People in their chains are worse off than Caribbean forced laborers or African slaves employed in California and brazilian plantations. Their wrists were stamped with letters and numbers.

This mining production finally got a profit in 1892, the forest, rice fields and gardens of the population had changed its function to become an industrial city space in the interior of West Sumatra. The buildings in sawahlunto are dominated by colonial architecture with a dormer characteristic on the roof, while the pacinan architecture symbolizes the existence of Chinese ethnicity in the past. The construction of this building is still in existence even though it is a century old. The urban planning of sawahlunto in colonial times was very well patterned to support mining activities, housing for high ranking mining employees was placed in a certain zone close to trade facilities, while mining workers' settlements were located far on the outskirts of the city, service and commercial zones were placed in the city center to serve their needs. and the lifestyle of colonial officials. This pattern is still maintained until now, if Jakarta has an Old City, West Sumatra also has an Old Town which is located in Sawhalunto.

The administrative area of Sawahlunto underwent regional expansion in 1990, resulting in the appearance of the terms old town and new town. The old town is a city that was built during the Dutch colonial era with the characteristic of Indische architecture which is a mining center. The new city is an administrative expansion area that has increased by 50 times from the beginning.

\subsection{Ombilin Coal Mine Site as a Source of Learning History}

The town of sawahlunto is a city that grows because of their natural wealth, namely Batu Bara. The town of sawahlunto has three sub-districts that are characterized by urban 
areas, first, Silungkang is a city famous for its weaving and songket crafts, second, the old town which is located in the fresh Valley sub-district, third, Talawi which is located in the northern part of the city of Sawahlunto. These cities reflect the local identity that is very thick from the pedalam areas of West Sumatra, these three cities are in one lane. The old town of sawahlunto can be used as a learning resource for economic history courses based on outdor learning. Various kinds of relics of the Dutch colonial era that have been made cultural heritage by the local government include

\section{a. Railway Museum}

The railway museum used to be a train station during the Dutch colonial administration, functioned in the past to load coal to be transported to the field. When the coal mine was closed, this station was no longer functioning and then renovated into a Railway museum opened since 2005. This museum has a collection of items related to railway technology, namely miniature steam locomotives, ancient clocks, steam kettles, steel safes which consist of of the two large and medium sizes used to store money and valuable objects at that time, tut morse was used to make morse code, morse current divider for incoming and outflow flows, morse current determinants, morse amperage is useful for checking battery conditions Morse, an inductor that functions as a track electricity generator for the use of a bell as well as to alert the train that someone will pass.

Track guard bell is a collection in the railway museum as a means of receiving orders sent using an inductor that the train will enter the track. The lantern lights are used by road inspectors to see the entire condition of the tracks to be traversed by the train. This street inspector works by walking from one station to another. The grinder is a collection found in the train museum, this tool is for sharpening iron. Outside the museum there is the Dutch colonial government Zamam Railway. In this museum, there is a documentary film about the history of railways in Sawahlunto which is about 20 minutes long. The construction of this railway museum is not as easy as imagined because there is a process of repatriating the steam locomotive which has migrated to Ambarawa to complete the museum's collection. This locomotive is then used to run tourist trains as makitam. And this woman is one of the icons of sawahlunto.

\section{b. Mbah Soero Mine Hole Site}

Mbah Soero's hole in the Dutch era was called the Soegar Hole which was the hole in the early period. In making this coal mine there is a dark history of the workers, namely chain people. The chain people were Dutch workers from the island of Java who were then forced to work as mining workers led by Mbah Soero. This coal mine pit during the early Dutch colonial rule employed Chinese workers from Singapore and Penang as well as from various Dutch Hindi regions such as Java, Madura, Bugis, Batak and Sundanese as well as local residents. The Dutch colonial government also employed prisoners (chain people) to save expenses. The estimated amount of coal in the sawahlunto area is around 197,000,000 the number of stones with a distribution of 20,000,000 in the parambah area, Sigalut has $80,000,000$ coal, Duren River is approximately 93,000,000 and Loerah Gadang is less than other areas with 4,000. 000 coals.

Coal mining in sawahlunto by the Dutch colonial began from 1892 to 1942 , when the Jpeang occupation of Indonesia was taken over by the Japanese (1942-1945). After independence this mine was taken over by the Government of the Republic of Indonesia in various statuses, namely

1. In 1945-1958 this coal mine was held by the Mining Directorate 
2. 1961-1968 there was a shift to the General Bureau of the State Mining Company under the general leadership of the coal mine.

3. 1970-2016 in the auspices of the Bukit Asam Mining State Company and Ombilin. In 1980 this company changed to become a Persero which manages development. 30 October 1990 This Company was merged into PT. Bukit Asam mine so that this mine has the status of the Ombilin mining unit.

The mining which was turned into a museum is mining during the Dutch Colonial era which has long been closed, opened again during the period of Mayor Amran Nur. This mbah Sero mine hole is close to the settlement so it is used as an underground tourist attraction and is suitable for the recovery of economic history based on outdoor learning that is not only fixed in the classroom. This mine hole is equipped with relatively good security. It is proven when the researchers visited this place that a guide was provided to explain about this mine hole. If you want to enter this mine hole, special shoes and a special hat must be provided for safety. Inside the Mbah Soero museum, there are various kinds of chains used for workers in the Dutch colonial era, axes for mining tools, shovels, foreman's hats, and foreman's clothes which are historical witnesses of past events.

\section{c. Sawahlunto Coal Mining Museum}

The coal mining museum was built by the Ombilin Coal Mining Company (PTBA UPO) by utilizing an old building in the middle of the old city. The location is located in a public room called a triangle field. This field was originally the front yard of PTBA UPO's main office then changed to become a city Tama. Renovation of the old building as the revitalization of the old town of Sawahlunto, was also carried out in a number of buildings, one of which is the cultural center building, this building is used for social, cultural and artistic activities. The old town market (youth market) was also revitalized here a 4dimensional cinema was built.

This coal mining museum exhibits mining equipment that was used in mine pits, archives, miner's clothes, coal conveying vehicles and coal sorting machines. This museum provides documentary films about the development of the mining industry in Sawahlunto since the Dutch colonial era until now. This museum serves as historical evidence of the triumph of the coal mining industry in Sawahlunto.

\section{d. Goedang Ransoem Museum}

Goedang Ransoem was established in 1918 as a public kitchen. The public kitchen during the Dutch colonial era was useful for cooking food for the needs of thousands of mining workers and hospitals. This public kitchen is equipped with two large warehouses and a power strom (furnace) with approximately 1000 employees. This public kitchen can cook as much as 65 pikul per day, equivalent to $39,000 \mathrm{~kg}$ of rice. This food is for mining workers, hospital patients and family of mine workers. Before the mining company built a public kitchen, there was a change in the person in charge of food, namely first, before 1912, food for workers was supplied by a Chinese who had been contracted by the Dutch colonial, because it was not supervised, which resulted in poor quality of food ingredients and little variation in food. Second, the Dutch colonial government in 1912-1918 took over the task of distributing food by appointing a staff member and three guards who were responsible for food, but this system did not work because of the corruption they committed. Third, in 1918 the mining company built a Public Kitchen so that it could provide food in large quantities, thus answering the problem of a food supply that had happened before.

As a place to cook for thousands of people, this soup kitchen uses a large number of utensils for random activities. Three large furnaces are prepared to produce hot steam for 
cooking food in the soup kitchen. Public kitchens also handle the food distribution system in several ways:

1. Food for overseas people is delivered by officers to the location where they work, this food is brought by truck (chavial) with a Chinese driver. The chain people pick up food in the warehouse right they do the mining

2. Food for employees who do not have a family, especially those from the Netherlands, they get a 6 month free food ration, after which their salary is taken. In taking this food they have to queue to get rice, side dishes and vegetables. The purpose of queuing is so that there is no fighting over food

3. Food for mining workers with families, they get a food ration according to the number of families, they are given in the form of raw materials not cooked

4. Food for hospital workers and patients is delivered by truck, this food is first weighed at the hospital's food weighing station, delivered by truck

Food for workers will be weighed in the food weighing room for inspection and knowing the number of food portions that have been determined. In addition to the weighing room, there is an underground control room which aims to see the pipes that distribute hot steam to the steam stove, in the public kitchen there is also a foreman's rest area measuring $4.3 \times 2.3 \mathrm{~m}$, and there is a room to wash all food ingredients and space rest workers and raw material warehouse. In the Dutch colonial era, there were factories and ice warehouses used for the needs of the Dutch as well as hospitals and preserving foods such as fish, meat.

In Japanese times cooking activities were still carried out in large numbers. In the 1950s there was a decrease in the activity used by the community for cooking. Mid-1970s this place was used as an educational facility and housing for employees of the Ombilin coal mine until 1980, after which it was used as a community residence until 2005. After that this place was conserved so that history would not be lost inaugurated by Jusuf Kalla (at that time as vice president).

\section{Research Methods}

This study uses a qualitative method with a descriptive study approach because this study seeks to reveal the history of the ombilin coal mine site, analyze the potential of this coal mine site for the economy, as well as education and make it a learning resource for economic history courses based on outdor learning. The location in this research will be carried out in Sawahlunto Sijunjung Regency in data collection data sources through printed media such as Singgalang newspapers, Korang Padang Express, Kompas, West Sumatra Cultural Heritage preservation center reports and literary literature. The sources of the photos that the researchers used were taken directly from the field as well as interviews with people who live near the Coal Mining Site.

The data sources for this study were collected, so that the primary and secondary sources were separated by means of passive observation that saw the condition of the Ombilin Coal Mine Site, then recorded, recorded and documented. After that the results of these observations were compared with the results of the interviews. The interview use a cellphone as a video capture recording device. In addition, researchers also collect books and journals related to this coal mine situation. After all the sources have been collected, interpretation and rewriting are carried out. 


\section{Discussion}

The Ombilin Coal Mine Site is a historical heritage place that can be used as a learning resource for economic history courses that can be done with outdoor learning. A learning resource is something that contains messages that can be displayed through pictures, videos or visiting directly to related learning resources. This learning resource based on outdor learning can build historical awareness and the spirit of nationalism in history education study program students.

This Coal Mine Site is suitable in learning the dynamics of the Dutch colonial economy and its impact on Indonesian society. With the use of this coal mining site based on outdor learning as an attractive recovery method as well as complementing student knowledge about mining carried out by the Dutch in Indonesia, especially on the island of Sumatra. Usually, the material that is often discussed in the recovery room tends to be learning resources on the island of Java. Inviting students to direct historical witnesses, especially the coal mining site, which consists of the railway museum, the Mbah Soero coal mine, the coal mining museum and the Goedang Ransoem, as well as the hospital which is still used as the sawahlunto hospital. It is hoped that with this outdor learning-based learning students will begin to be literate about the history of the Indonesian nation, have historical awareness, a spirit of patriotism and nationalism that will love their nation more. In outdoor learning-based recovery, thorough preparation is needed so that students arrive in the field not only to take photos but they can conduct interviews with the question instruments they have made and after completing a visit at this coal mine site, students make a paper or a video about this coal mine site and a research report.

This outdoor learning-based recovery, lecturers in the field must also emphasize to students that historical heritage, both local and national, must be preserved by all groups such as the government, society and the academic community. This outdoor learning-based recovery from early February 2020 until now is indeed a bit difficult to do because of the covid-19 outbreak that has attacked Indonesia. Lecturers can replace it by presenting photos, pictures and videos of this coal mining site in the lecture room. The alternative here is that the lecturers themselves make visits related to learning resources for the history of this coal mine site and take photos and videos needed for economic history material, especially the dynamics of the Dutch colonial economy in Indonesia. The photos are displayed using infocus and students are expected to discuss the ombilin coal mining site about the impact of mining by the colonial government in West Sumatra, as well as the dynamics of this mining.

The public's view of historical sites only considers it a storage place for past objects, because this assumption the lecturer must change it by answering all student questions by way of outdoor learning there students will get knowledge of how mining is done by the Dutch, the food served is arranged in portions, how there is a mixture of cultures due to the mining.

\section{Conclusion}

The Ombilin coal mine site can be used as a source of historical learning based on outdor learning for economic history courses with material on the dynamics of the Dutch colonial economy in Indonesia and its impacts. During the Dutch colonial era, they were not only extracting spices from Indonesia but also Indonesian plantation and mining products, one of which was in West Sumatra, the Ombilin coal mine. From this mine the Dutch colonial government had a big advantage. This mining area was revitalized by the Sawahlunto City government by establishing a museum, namely a railway museum, the 
Mbah Soero mine hole museum, the ransoem warehouse museum, a coal mine museum. All of these museums can be used as learning resources based on outdor learning so that historical recovery is not boring and focuses on books, taking students to the field will foster their values of nationalism.

\section{References}

Abdullah, Ramli. (2016). "Pembelajaran Sejarah Berbasis Pemanfaatan Sumber Belajar". Jurnal Ilmiah Didaktika Volume XII No. 2

Afandi, Muhammad, et al. (2013). Model dan Metode Pembelajaran di Sekolah. Universitas Islam Sultan Agung Semarang. Unissula Press.

Ariyani, Riska Wahyu \& Huda Khoirul. (2016). Situs Masjid Agung Sewulan (Sejarah dan Potensinya Sebagai Sumber Belajar Sejarah SMP/MTsN). Jurnal Agastya Vol 6 No 2.

Hafid, Abd. (2011). "Sumber dan Media Pembelajaran."Sulesana volume 6 nomor 2

Hamdani. (2011). "Strategi Pembelajaran". Bandung: CV. Pustaka Setia

Husamah. (2013). "Pembelajaran Luar Kelas Outdoor Learning". Jakarta: Prestasi Pustaka Jakarta

Kiswinarso, Hemy \& M. Hanif. (2016). Kebijakan Pemerintah Kabupaten Ponorogo Dalam Pelestarian Situs Peninggalan Sejarah Taun 2000-2015. Jurnal Agastya Vol 6 No 1.

Merdiana, Arie Dwita, Hamdan TA, dan Andy Suryadi. (2017). Pecinan Semarang Sebagai Sumber Belajar Sejarah Pokok Bahasan Kolonialisme Kelas XI IPS di SMA Nasional Nusaputera Semarang Tahun Pelajaran 2016/2017. Indonesian Journal of History Education. 5 (1).

M. Nur Faizah. (2012). Pemanfaatan Sumber Belajar Dalam Pembelajara SAINS Kelas V SD Pada Pokok Bahasan Makhluk Hidup dan Proses Keidupan. Jesbio Vol. 1 No.1.

Mursidi, Agus \& Soetopo Dahlia. (2019). Peninggalan Sejarah Sebagai Sumber Belajar Sejarah Dalam Penanaman Nilai-Nilai Kebangsaan di Kecamatan Muncar Kabupaten Banyuwangi. Jurnal Ilmiah Kependidikan. Vol XIII. No 1.

Oemar, Hamalik. (2003). Pendekatan Baru Strategi Belajar Mengajar Berdasarkan CBSA. Bandung: penerbit Sinar Baru Algesindo

Rahman, Aulia. (2019). Modernisasi Teknologi Kereta Api Di Sumatera Barat Masa Hindia Belanda (1871-1933). Jurnal Arkeologi Vol 24

Rizqi, Y. et al. (2020). Development of Local History Learning with the Heroism Theme of K. Gholib Based on E-Book for Private Vocational School Students in Pringsewu Regency. Budapest International Research and Critics in Linguistics and Education (BirLE) Journal. P. 1287-1300

Soebijantoro, et al. (2016). Situs Ngurawan Kecamatan Dolopo Kabupeten Madiun (Latar Sejarah Dan Upaya Pelestariannya). Agastya Vol 6

Styahran, Jailani M. (2016). Pengembangan Sumber Belajar berbasis Karakter Peserta Didik (Ikhtiar Optimalisasi Proses Pembelajaran Pendidika Agama Isllam (PAI)). Jurnal Pendidikan Islam Vol 10. No 2.

Sugiyono. (2005). Metode Penelitian Kualitatif dan Kuantitatif. Bandung: Alfabeta

Sugiyono. (2011). Metode Penelitian Kualitatif dan Kuantitatif. Bandung: Alfabeta

Sulistyo, Wahyu Djoko. 2019. Pemanfaatan Situs Sejarah Masa Kolonial di Kota Batu sebagai Sumber Pembelajaran Berbasis Outdoor Learning. IndonesianJournal of Social Science Education. Vol. 1 No 2.

Sundari. Hanna. (2015). Model-Model Pembelajaran dan Pemerolehan Bahasa Kedua/Asing. Jurnal Pujangga Vol 1 No 2. 
Supriadi. (2015). Pemanfaatan Sumber Belajar Dalam Proses Pembelajaran. Lantanida Journal Vol 3 No2.

Tejokusumo, Bambang. (2014). Dinamika Masyarakat Sebagai Sumber Belajar Ilmu Pengetahuan Sosial. Jurnal Geo Edukasi Vol III No. 1.

Tyas, K K M. (2018). Penggunaan Novel Sejarah Sebagai Sumber Belajar Sejarah. Jurnal Pendidikan Sejarah Vol 7 No 2.

Wibowo, Wisnu Edi. (2016). Upaya Meningkatkan Minat Belajar IPA Melalui Model Pembelajaran Outdoor Learning pada Siswa Kelas III SDN Mejing 2 Ambarketawang Gamping Sleman Tahun Ajara 2016/2017. Artikel. PGSD FKIP Universitas PGRI Yogyakarta. 